Vol.45, n. 3 : pp. 293-299, September 2002 ISSN 1516-8913 Printed in Brazil

\title{
Possible Associations between Bovine Growth Hormone Gene Polymorphism and Reproductive Traits
}

\author{
Maria Marina Unanian ${ }^{1 *}$; Cristine Chaves Barreto ${ }^{1}$; Célia Maria Torres Cordeiro ${ }^{1}$; \\ Alfredo Ribeiro Freitas ${ }^{2}$ and Luiz Antonio Josahkian ${ }^{3}$ \\ ${ }^{I}$ EMBRAPA - CENARGEN; Parque Estação Biológica - PqEB; Av. W 5 Norte; 70770-900; Brasília - DF - Brazil. \\ ${ }^{2}$ EMBRAPA - CPPSE; Rod. Wahington Luiz km 234; 13560-970; São Carlos - SP - Brazil. ${ }^{3}$ ABCZ; Pça. Vicente \\ Rodrigues da Cunha 110; 38022-330; Uberaba - MG - Brazil
}

\begin{abstract}
The polymorphism of the bovine growth hormone gene (bGH) was studied in 211 Nellore pure breed males for association with reproductive traits. Scrotal circumference and testosterone concentrations were collected monthly from 10 until 16 months of age. Additionally, testicular growth rates were calculated. DNA was amplified by PCR and digested using Msp I and Hae III restriction enzymes. Every polymorphism presented two alleles. The predominant alleles were $D(0.85)$ and $F(0.98)$, respectively, and genotype EE - bGH/Hae III was missing. Significant association $(P<0.05)$ between $b G H / M s p$ I polymorphism, scrotal circumference and testicular growth after puberty, as well as between bGH/Hae III and testosterone concentrations at puberty were detected. The results suggested that these association could be useful for selection, since bGH/Msp I and bGH/Hae III polymorphisms could be considered as markers for testicular development after puberty and onset of puberty, respectively.
\end{abstract}

Key words: Bull, growth hormone gene polymorphism, testosterone concentrations

\section{INTRODUCTION}

Molecular genetic markers in breeding progr ams could make selection more precise and efficient. Some of these markers are called candidate genes, e.g. the growth hormone genes, which are usually selected because of their biological significance on the quantitative traits of interest. Growth hormone has wide physiological activities, which include the regulation of growth, lactation and mammary gland development, gluconeogenesis, the activation of lipolysis, and the enhancement of amino acid incorporation into muscle protein (Burton et al., 1994). There is also evidence that growth hormone may be involved in the pubertal development and testicular function (Lin, 1996). The role of growth hormone in testicular function has been studied in immature dwarf mice $(\mathrm{dw} / \mathrm{dw})$. Treatment of these mice with reco mbinant human growth hormone increased body, liver and testicular weight. It also increased the number of testicular LH receptors and steroidogenic responses to hCG, which stimulated an increase in testosterone level (Chatelain et al., 1991). In prepubertal boars it was demonstrated that growth hormone treatment advanced the onset of spermatogenesis (Swanlund et al., 1995). Molecular genetic studies have confirmed considerable polymorphism of the bovine growth hormone gene and association of some of these

* Author for correspondence 
polymorphic sites with production traits such as milk and body weight gain (Yao et al., 1996; Rocha et al., 1992; Schelee et al., 1994; Moody et al., 1996). However, association of the effect of the growth hormone gene with reproductive traits is scarce (Lechniak et al., 1999). The purpose of the present study was to investigate the possible association of the bovine growth hormone gene polymorphisms with reproductive traits of interest, in order to identify potential markers to be used as complementary parameters in the selection of pure breed Nellore bulls (Bos indicus).

\section{MATERIALS AND METHODS}

Animals: Two hundred and eleven pure breed Nellore males (Bos indicus) from six herds were used. The animals (10 to 16 month) were raised extensively on pasture. Measures of scrotal circumference $(\mathrm{SC} / \mathrm{cm})$ and weight $(\mathrm{W} / \mathrm{kg})$ were taken once a month. On the same day ejaculate and blood samples were collected. The bulls were grouped by the age of appearance of the first spermatozoa $\left(1^{\text {st }} \mathrm{Spz}\right)$ as follows: $\mathrm{I}^{\circ}$ group 292 to 339 days; II $^{\circ}$ group 340 to 377 days; III $^{\circ}$ group 378 to 434 days; and $\mathrm{IV}^{\mathrm{o}}$ group 435 to 525 days. Each group was composed of 52,52,53 and 54 bulls, respectively. The bulls reached puberty approximately one month after the 1st Spz appeared and the mating ability two and half months after puberty. The monthly SC was used to determine testicular growth $(\mathrm{TG} / \mathrm{cm})$. This was considered to be the difference between the measures of SC from 10 to 12 months and from 12 to $13,14,15$ and 16 months of age. The ejaculate was collected by electroejaculation and analyzed for sperm motility (MOT/\%), concentration (CONC/ $\times 10^{6}$ spermatozoids $/ \mathrm{ml}$ ) and morphology, the minor (MIN/\%) and major (MAJ/\%) defects. This analysis covered a period that started with the appearance of 1st Spz and finished at 16 months of age. Blood samples was collected from the jugular vein into non heparinized tubes and then after clotting for 6 hours, centrifuged at 1,500 x g for 15 min. Serum was decanted and stored at $-20^{\circ} \mathrm{C}$ until it could be assayed for testosterone. The testosterone concentrations (TEST/ng/ml) were determined in duplicate by RIA procedure according to Bèlanger et al., 1980. From every animal, $10 \mathrm{ml}$ of blood was collected into EDTA $\mathrm{K}_{3}(15 \%)$ tubes for DNA extraction. The genomic
DNA was purified from blood samples by a salt precipitation method (Miller et al., 1988).

PCR and RFLP: The PCR amplification was carried out in a $0.6 \mathrm{ml}$ PCR test tube mixing $2.0 \mu \mathrm{l}$ DNA (100 ng), $5 \mu 11 \times$ Tag Buffer (100 mM Tris $\mathrm{HCl}, 500 \mathrm{mM} \mathrm{KCl}, 15 \mathrm{mM} \mathrm{MgCl} 2,0.01 \%$ gelatin, and $1 \%$ Triton $\mathrm{X}-100 ; \mathrm{pH} 9.0), 3.0 \mu \mathrm{MgCl}_{2}(1.5$ $\mathrm{mM}), 1.0 \mu \mathrm{l} \mathrm{dNTP}(200 \mu \mathrm{M}), 0.4 \mu \mathrm{l}$ Taq DNA polymerase $(2 \mathrm{U})$ and $1.5 \mu 1$ Primers $(0.8 \mathrm{mM})$, in a final volume of $50 \mu \mathrm{l}$. The bGH was amplified using the following oligos as primers:

a. forward primer 5' - ATC CAC ACC CCC TCC ACA CAG T - 3'; reverse primer 5'- CAT TTT CCA CCC TCC CCT ACA G - 3'; Zhang et al., 1993; and

b. forward primer 5'- ACG CGC TGC TCA AGA AC - 3'; reverse primer 5' - GGC TGG AAC TAA GAA CC - 3'; Unanian et al., 1994.

The programmed cycles for the PCR reaction were: one cycle at $97^{\circ} \mathrm{C}$ for 1.5 minutes, one at $62{ }^{\circ} \mathrm{C}$ for 1 minute, one at $72{ }^{\circ} \mathrm{C}$ for 1 minute; 48 cycles at $94^{\circ} \mathrm{C}$ for 30 seconds, $62^{\circ} \mathrm{C}$ for 60 seconds and $72^{\circ} \mathrm{C}$ for 30 seconds; and an extension of one cycle at $72{ }^{\circ} \mathrm{C}$ for 4 minutes. The "a" primers were designed to amplify a 891 base pair (bp) fragment of the bGH consisting of the intron 2 ( 3 ' region), exon III, intron 3, exon IV and intron 4 ( 5 ' region), and the " $\mathrm{b}$ " primers amplified a $441 \mathrm{bp} \mathrm{PCR} \mathrm{product} \mathrm{containing} \mathrm{the} \mathrm{exon} \mathrm{V}$ and 3' flanking region of the bGH gene.

Ten $\mu l$ of the PCR product obtained with "a" and "b" primers was digested with the restriction enzymes Msp I (15 U Msp I, $1.5 \mu$ l buffer) and Hae III (10 U Hae III, $2.0 \mu$ l buffer, $0.04 \mu \mathrm{l}$ BSA $/ 100 \mu \mathrm{g} / \mathrm{ml}$ ), respectively. After digestion, $10 \mu \mathrm{l}$ of each product was mixed with $2 \mu$ l loading buffer $(0.25 \%$ Xylene Cyanole FF, $40 \%$ w/v sucrose in water) and separated on $3 \%$ agarose gel in $1 \mathrm{x}$ TBE buffer (0.09 M Tris-borate, $0.002 \mathrm{M}$ EDTA) and $0.5 \mu$ l ethidium bromide water solution (10 $\mathrm{mg} / \mathrm{ml}$ ). Genotype was determined from the size of restriction fragments by comparison with DNA molecular weight markers.

Statistical analysis: All data were analyzed by least-square analysis of variance using the GLM procedure of SAS (SAS, 1996). The quantitative variables (TEST, SC and TG) were adjusted by contemporary groups and farm. The contemporary groups were established based on season and year of birth. Farm included the bulls, herd, 
environmental and management effects. The weights are not reported in this study, but were included in the statistical analysis as covariables.

The model used to analyze the association of bGH polymorphisms (bGH/Msp I and bGH/Hae III) with TEST and TD, evaluated monthly, can be represented in matrix notation as:

$$
\mathbf{Y}=\mathbf{X}_{1} \beta_{1}+\mathbf{X}_{2} \beta_{2}+\mathrm{e}
$$

where $\mathbf{Y}$ is an $\mathbf{n} \times 1$ vector of observations ( $\mathbf{n}=211$ animals); $\mathbf{X}_{\mathbf{1}}$ and $\mathbf{X}_{\mathbf{2}}$ are known incidence matrices of order $\mathbf{n} \times 14$ and $\mathbf{n} \times 5$ relating location parameters $\beta_{1}$ and $\beta_{2}$, respectively, to $\mathbf{Y} ; \beta_{1}$ is a 14 $\times 1$ vector of systematic effect, including the effect of farm (six levels), contemporary groups (seven levels) and one regression coefficient corresponding to the weight of animal collected monthly; $\beta_{2}$ is a $5 \times 1$ vector of fixed effects including the effect of bGH/Msp (genotypes CC, $\mathrm{CD}, \mathrm{DD}$ ) and bGH/Hae III (genotypes EF, FF); and $\mathbf{e}$ is a $\mathbf{n} \times 1$ vector of random residual effects The distribution assumptions in the model were:

$$
\sigma_{\mathrm{e}}^{2} \sim \mathbf{N}\left(\mathbf{0}, \mathbf{I}_{\mathrm{e}} \sigma_{\mathrm{e}}^{2}\right)
$$

where $\mathbf{I}_{\mathbf{e}}$ is the identity matrix $(\mathbf{n} \times \mathbf{n})$ and $\sigma^{2}$ the residual variance component.

The statistical analysis for TEST was performed using natural logarithm transformed values to obtain an approximate normal distribution of errors and more homogeneous residual variance. The least-squares means of genotypes were retransformed by antilog to geometric means with approximate standard errors calculated as $\mathrm{e}^{(\hat{y} \text { +s.e.m.) }}-\mathrm{e}^{\hat{y}}$.

The MOT, CONC, MIN and MAJ were transformed using $\sqrt{ }(x+0.5)$. The same matrix model was adopted where the vector $\beta_{1}$ included the systematic effects of farms and sires within farms; the vector $\beta_{2}$ included the effects of class of animals grouped by age of the $1^{\text {st }} \mathrm{Spz}$ and fixed effects of bGH/Msp I (genotypes CD, DD) and bGH/Hae III (genotypes EF, FF). As only one animal had bGH/Msp I - CC genotype, it was not included in the model. The frequencies of animals classified into types of genoty pes and of animals grouped by age of appearance of $1^{\text {st }} \mathrm{Spz}$ were tested by Mantel-Haenszel chi-square analysis using FREQ procedure of SAS (SAS, 1996).

\section{RESULTS}

Genotype and allele distribution: For each polymorphism two alleles were detected according to their restriction fragment lengths. PCR product digested with restriction enzyme Msp I revealed four and three fragments designated as allele $\mathrm{C}$ (526, 193, 109, and $63 \mathrm{bp})$ and allele D $(635,193$ and $63 \mathrm{bp}$ ), respectively. The digestion with Hae III generated the $\mathrm{E}$ and $\mathrm{F}$ alleles. The $\mathrm{E}$ allele product exhibited three fragments of $268 \mathrm{bp}, 102$ $\mathrm{bp}$ and $71 \mathrm{bp}$. The F allele, in addition to the same $268 \mathrm{bp}$ and $102 \mathrm{bp}$ fragments, had an observable band of about $50 \mathrm{bp}$ in length instead of a $71 \mathrm{bp}$ band. The genotype and allele frequencies are shown in Table 1. Three genotypes (CC, CD and DD) were observed for bGH/Msp I polymorphism and two genotypes (FF and EF) for bGH/Hae III. The CC genotype (bGH/Msp I) was found in only three animals, their results not being presente $d$. The EE genotype (bGH/Hae III) was missing. The frequencies of the $\mathrm{D}$ and $\mathrm{F}$ allele were 0.85 and 0.98 , respectively, and 0.15 and 0.02 for the alleles $\mathrm{C}$ and $\mathrm{E}$, respectively.

Association analysis: Grouping the bulls by appearance of $1^{\text {st }} \mathrm{Spz}, 104$ animals presented puberty at 12.2 months of age on average, and 107 at 15 months of age. The maturity of the 104 bulls occurred at 15 months of age. Significant association between the age of $1^{\text {st }} \mathrm{Spz}$ appearance and the bGH polymorphisms were not observed $(\mathrm{P}>0.919)$.

Table 1 - Genotype and allele frequencies (\%) of growth hormone gene in Nellore pure breed bulls.

\begin{tabular}{cccccc}
\hline Polymorphism & Genotype & N & $\%$ & Allele & $\%$ \\
\hline Msp I & CC & 3 & 0.01 & C & 0.15 \\
& CD & 56 & 0.27 & D & 0.85 \\
& DD & 152 & 0.72 & & \\
\hline Hae III & FF & 182 & 0.96 & F & 0.98 \\
& EF & 8 & 0.04 & E & 0.02 \\
\hline
\end{tabular}

$\mathrm{N}=$ number of animals 
There were non significant $(\mathrm{P}>0.05)$ associations between $\mathrm{bGH} / \mathrm{Hae}$ III or bGH/Msp I genotypes and sperm MOT, CONC, MIN and MAJ. Several association were found for the bGH/Msp I polymorphism (Table 2 and 3). For SC (Table 2) a difference was detected between heterozygous (CD) and homozygous (DD) at 16 months of age $(\mathrm{Pr}<\mathrm{F}$ 0.0333), where the $\mathrm{CD}$ animals presented higher SC. No other association was observed concerning the SC.

The bulls that inherited the CD genotype showed a higher TG than DD animals from 12 to 15 months
$(\operatorname{Pr}<\mathrm{F} 0.0340)$ and from 12 to 16 months of age $(\operatorname{Pr}<\mathrm{F} 0.0094)$ (Table 3).

One statistically significant association with TEST (Table 4) for bGH/Hae III polymorphism was found. The TEST value of the heterozygous (EF) bulls at 12 months of age was significantly higher $(\mathrm{Pr}<\mathrm{F} 0.0019)$ than of the homozygous (FF), with differences of $7.08 \mathrm{ng} / \mathrm{ml}$ (EF-FF). Furthermore, a difference between EF and FF bulls at 13 months of age was observed, when the EF bulls presented a higher TEST $(\operatorname{Pr}<\mathrm{F} 0.0435)$ with differences of $3.09 \mathrm{ng} / \mathrm{ml}$ (EF-FF).

Table 2 - Least squares means $( \pm \mathrm{SE})$ of scrotal circumference for growth hormone gene by age in Nellore pure breed bulls.

\begin{tabular}{ccccccc}
\hline $\begin{array}{c}\text { Polymorphism/ } \\
\text { Genotype }\end{array}$ & & $12(155)^{*}$ & $13(155)$ & $14(156)$ & $15(100)$ & $16(59)$ \\
\hline bGH/Msp I & CD & $19.68 \pm 0.42$ & $21.42 \pm 0.53$ & $22.34 \pm 0.57$ & $24.04 \pm 0.63$ & $23.90 \pm 0.79^{\text {a }}$ \\
& DD & $20.32 \pm 0.34$ & $21.67 \pm 0.43$ & $22.23 \pm 0.51$ & $23.66 \pm 0.49$ & $22.03 \pm 0.80^{\text {b }}$ \\
bGH/Hae III & FF & $19.99 \pm 0.33$ & $21.37 \pm 0.45$ & $22.36 \pm 0.50$ & $23.56 \pm 0.54$ & $23.88 \pm 0.75$ \\
& EF & $19.74 \pm 0.80$ & $21.80 \pm 1.06$ & $20.65 \pm 1.25$ & $23.40 \pm 1.05$ & $23.83 \pm 2.75$ \\
\hline
\end{tabular}

* (Number of animals)

${ }^{\mathrm{a}, \mathrm{b}}$ Means at 16 months of age are statistically different $(\operatorname{Pr}<\mathrm{F} 0.0333)$

Table 3 - Least squares means $( \pm \mathrm{SE})$ of testicular growth for the growth hormone gene by age intervals in Nellore pure breed bulls.

\begin{tabular}{ccccccc}
\hline \multicolumn{2}{c}{$\begin{array}{c}\text { Polymorphism/ } \\
\text { Genotype }\end{array}$} & 10 to $12(58)^{*}$ & 12 to $13(110)$ & 12 to $14(111)$ & 12 to $15(84)$ & 12 to $16(35)$ \\
\hline bGH/Msp I & CD & $1.70 \pm 0.47$ & $1.59 \pm 0.40$ & $3.19 \pm 1.03$ & $4.99 \pm 0.62^{\mathrm{a}}$ & $4.76 \pm 0.91^{\mathrm{a}}$ \\
& DD & $1.90 \pm 0.42$ & $1.46 \pm 0.38$ & $2.87 \pm 0.95$ & $4.19 \pm 0.55^{\mathrm{b}}$ & $3.37 \pm 0.93^{\mathrm{b}}$ \\
$\mathrm{bGH} / \mathrm{Hae}$ III & FF & $2.18 \pm 0.47$ & $1.32 \pm 0.47$ & $2.86 \pm 1.07$ & $3.66 \pm 0.59$ & $3.69 \pm 0.64$ \\
& EF & $2.23 \pm 0.70$ & $1.13 \pm 0.63$ & $2.04 \pm 1.21$ & $3.80 \pm 0.86$ & $2.68 \pm 1.46$ \\
\hline
\end{tabular}

* (Number of animals)

${ }^{\mathrm{a} b}$ Means at 12 to 15 months interval age are statistically different $(\operatorname{Pr}<\mathrm{F} 0.0340)$

${ }^{\mathrm{a}, \mathrm{b}}$ Means at 12 to 16 months interval age are statistically different $(\operatorname{Pr}<\mathrm{F} 0.0094)$

Table 4 - Least squares means ( \pm SE) of blood testosterone concentrations for bovine growth hormone gene by age in Nellore pure breed bulls.

\begin{tabular}{ccccccccc}
\hline \multicolumn{2}{c}{$\begin{array}{c}\text { Polymorphism/ } \\
\text { Genotype }\end{array}$} & $10(43)^{*}$ & $11(69)$ & $12(77)$ & $13(64)$ & $14(58)$ & $15(47)$ & $16(25)^{* *}$ \\
\hline bGH/Msp I & CD & $1.20 \pm 1.10$ & $0.73 \pm 0.55$ & $2.43 \pm 1.36$ & $1.27 \pm 0.75$ & $0.46 \pm 0.30$ & $1.64 \pm 0.94$ & $1.78 \pm 0.46$ \\
& DD & $0.90 \pm 0.76$ & $1.23 \pm 0.90$ & $2.58 \pm 1.47$ & $2.19 \pm 1.26$ & $0.87 \pm 0.60$ & $1.41 \pm 0.68$ & $1.76 \pm 0.68$ \\
bGH/HaeIII & FF & $0.71 \pm 0.28$ & $0.55 \pm 0.16$ & $0.80 \pm 0.21^{\mathrm{a}}$ & $0.71 \pm 0.39^{\mathrm{a}}$ & $0.78 \pm 0.34$ & $1.52 \pm 0.72$ & $2.59 \pm 0.62$ \\
& EF & $1.53 \pm 2.80$ & $1.63 \pm 2.74$ & $7.88 \pm 9.36^{\mathrm{b}}$ & $3.80 \pm 5.11^{\mathrm{b}}$ & $0.51 \pm 0.84$ & - & - \\
\hline
\end{tabular}

* (Number of animals)

** Observed data

a, b Means at 12 months of age are statistically different $(\operatorname{Pr}<\mathrm{F} 0.0019)$

a, b Means at 13 months of age are statistically different $(\operatorname{Pr}<\mathrm{F} 0.0435)$ 


\section{DISCUSSION}

In this study the average frequency of the bGH/Msp I - DD genotype of 0.72 was similar to the other frequencies reported for the Nellore population. Borges, 1997 found a genotype proportion of 0.78 among 107 Nellore young bulls, which was 0.71 as reported by Rodrigues et al., 1998 among 42 Nellore bulls. The D-allele frequency of 0.85 in this study was similar to 0.86 achieved by Mitra et al., 1995 among 42 Shiwal zebu, and to 0.88 and 0.84 described in Nellore by Borges, 1997 and Rodrigues et al., 1998, respectively. In a study with several beef breeds, Theilmann et al., 1998 did not find the D-allele in American herds of Angus, Hereford and Longhorn. This allele appeared only in Brahman. The results found here showed that the bGH/Msp I D-allele might be characteristic of Bos indicus animals. This allele was associated with milk production, protein and fat (Yao et al., 1996) and with body weight gain (Rocha et al., 1992). Originally, the Nellore was selected for milk production. In the last 20 years as the use of this breed spread, the animals began to be selected for meat production. It is possible that the milk and meat selection were responsible for increasing of the D-allele frequency. On the other hand, the results could be due to genetic drift, once the selection was done using a relative small number of high performances AI bulls, whose alleles became widely distributed in the population, eliminating the alleles of low performance bulls and their progeny.

The bGH/Hae III - FF genotype was dominant in this Nellore population: 186 animals presented the F-allele and only four E-allele. Unanian et al., 1994 found the $\mathrm{F}$-allele only in Brahman (1.0; $\mathrm{n}=18$ ) among five beef bulls bred. Other references about the bGH/Hae III polymorphism were not found. In this study there was a tendency for more animals to be homozygous than heterozygous for the most frequent alleles.

The association between the bGH/Msp I polymorphism and testicular development could be a consequence of a direct effect of the growth hormone $(\mathrm{GH})$ or induced by factors involved with growth. It is known that the postnatal growth is primarily controlled by $\mathrm{GH}$ and insulin-like growth factor I (IGF I) (Hammon and Blum, 1998). In the testis, the growth hormone may act directly through GH receptors in the Sertoli cells (Mathews et al., 1989), or indirectly via local production of IGF I which mediates the growth hormone effect in the testis (Chatelaine et al., 1991; Dombrowicz et al., 1991). In addition, the action of the $\mathrm{GH}$ was probably testosterone dependent, since in hemi-castrated neonatal bulls no testicular development occurred until the onset of puberty, when the testosterone was secreted at higher levels (Al-Haboby et al., 1988). In this study, this could explain why the higher rates of testicular growth initiated after 12 months of age. At this time, puberty was detected through sperm characteristics (results not shown) and testosterone concentrations, both similar to the results reported by Lunstra et al., 1978. This observation has been supported by the experiments of McDonald and Deaver, 1993 in normal prepubertal bulls. These experiments demonstrated that GH did not have stimulatory effects on testicular function before puberty. However, these effects were observed in prepubertal bo ars, being probably controlled by testosterone. The testosterone levels in prepubertal boars are higher than in bulls (Swanlund et al., 1995). This suggested that the testicular development observed in this study after puberty was under the effect of testosterone secretion, which induced the effect of the growth hormone gene, since the expression of the gene involved with growth is androgen dependent (Stryer, 1988). On the other hand, Borges, 1997) and Rocha et al., 1992 related the bGH/Msp I polymorphism to body weight and body weight gain, the latest being highly correalted with scrotal circumference $(0.80$; Lunstra et al., 1978). This fact may also explain the influence of the growth hormone gene on male gonadal development.

The other association detected in this study was that of testosterone concentration and bGH/Hae III polymorphism, where EF genotype bulls presented higher concentrations, similar to the levels described by Lunstra et al., 1978 at puberty. The testosterone stimulates the growth hormone releasing hormone mRNA (GHRH-mRNA) expression in neurons of the hypotalamus. This activity has been demonstrated in castrated adult rats where a decrease of GHRH-mRNA levels occurred and the treatment with physiological levels of testosterone prevented this reduction (Zeitler et al., 1990). As noted earlier, the expression of the genes involved with growth is androgen dependent (Stryer, 1988). The influence of testosterone on growth hormone secretion was demonstrated by Jansson et al., 1985 in male adult 
rats. The authors concluded that testicular androgens that were secreted during neonatal period, irreversibly induced the secretory pattern of GH. The serum testosterone concentrations in cattle were low until puberty (Foote et al., 1976; Lunstra et al., 1978). However, after puberty it reached high levels (Lunstra et al., 1978), which probably contributed to the secretory pattern of growth hormone (Jansson et al., 1985).

The suggestion that the testosterone, according to the level, influences GH secretion and gene expression, probably explains the association of this steroid hormone and the bGH/Hae III polymorphism. This association could be an important finding, because it was observed in bulls considered precocious in comparison with the others.

The sperm traits were not associated with the growth hormone gene polymorphisms under study. These results were consistent with those of Lechniak et al., 1999 described for beef cattle.

In conclusion, the results of the present investigation suggested that the $\mathrm{bGH} / \mathrm{Msp} \mathrm{I}$ and bGH/Hae III polymorphisms could be potential markers for testicular growth after puberty and the onset of puberty. However, a definitive conclusion requires further studies with a larger number of bulls.

\section{ACKNOWLEDGEMENTS}

The authors thank Dr. Alzira A. Rosa e Silva for hormone assays and Dr. Antonio Emidio D. Feliciano Silva for help with sample and data collection. This research was supported in part by the Brazilian Zebu Breeders Association (ABCZ) and Faculty of Agronomy and Animal Science Uberaba (FAZU).

\section{RESUMO}

Em 211 machos da raça Nelore, PO, foi estudada a associação entre os polimorfismos do gene do hormônio de crescimento bovino (bGH) e características reprodutivas. Para o estudo foram realizadas medições mensais da circunferência escrotal e concentração de testosterona dos 10 aos 16 meses de idade e, ainda foi calculada a taxa de crescimento testicular. O DNA foi amplificado por PCR e digerido com as enzimas de restrição Msp I e Hae III. Cada um dos polimorfismos obtidos apresentou dois alelos. Os aleleo D $(0,85)$ e F $(0,98)$ predominaram na população estudada. Não foram encontrados animais portadores do genótipo $\mathrm{EE}$ do polimorfismo bGH/Hae III. Houve associação significativa $(\mathrm{P}<0,05)$ entre $\mathrm{o}$ polimorfismo $\mathrm{bGH} / \mathrm{Msp}$ I, a circunferência escrotal e o crescimento testicular após a puberdade e, ainda, entre o polimorfismo do bGH/Hae III e a concentração da testosterona na puberdade. Os resultados sugerem que os polimorfismos bGH/Msp I e bGH/Hae III poderiam ser considerados marcadores do desenvolvimento testicular e o aparecimento da puberdade. Pela importância das observações, em função do reduzido tamanho da amostra, os estudos devem prosseguir.

\section{REFERENCES}

Al-Haboby, A. H.; Loseth, K. J.; Wheaton, J. E. and Crabo, B. G. (1988), Neonatal hemiorchidectomy of bulls alters plasma growth hormone levels and advances onset of pubertal testosterone secretion. Domest. Anim. Endocrinol., 5, 60-69.

Bèlanger, A.; Caron, S.; Picard, V. (1980), Simultaneous radioimmunoassay of progestins, androgens and estrogens in rat tests. J. Steroid. Biochem., 13, 185-190.

Borges, M. (1997), Marcadores moleculares e seus efeitos sobre características quantitativas do bovino de corte. MSc Thesis, Universidade Federal de Uberlândia, Uberaba, MG.

Burton, J. L.; McBride; B. W.; Block, E.; Glimm, D. R. and Kennelly, J. J. (1994), A review of bovine growth hormone. Can. J. Anim. Sci., 74, 167-201.

Chatelain, P. G.; Sanchez, P. and Saez, J. M. (1991), Growth hormone and insulin-like growth factor I treatment increase testicular luteinizing hormone receptors and steroidogenic responsiveness of growth hormone deficient dwarf mice. Endocrinol., 128, 1857-1862.

Dombrowicz, D.; Hooghe, P. E.; Gothor, A.; Sente, B.; Vanhaelst, I.; Closser, J. and Hennen, G. (1991), Cellular localization of IGF-I and IGF-II mRNA in immature hypophysectomized rat testis and epididymis after in vitro hormonal treatment. Arch. Int. Physiol. Biophys., 100, 303-308.

Foote, R. H.; Munkenbeck, N. and Greene, W. A. (1976), Testosterone and libido in Holstein Bulls of various ages. J. Dairy Sci., 59, 2011-2013.

Hammon, H. and Blum, J. W. (1998), Endocrine and metabolic changes in neonatal calves in response to growth hormone and long- $\mathrm{R}^{3}$-insulin-like growth factor-I administration. Biol. Neonate, 73, 121-128. 
Jansson, J. O.; Ekberg, S.; Isaksson, O.; Mode, A. and Gustafsson, J. A. (1985), Imprinting of growth hormone secretion, body growth, and hepatic steroid metabolism by neonatal testosterone. Endocrinol., 117, 1881-1889.

Lechniak, D.; Machnik, G.; Szydlowski, M. and Switonski, M. (1999), Growth hormone gene polymorphism and reproductive performance of AI bulls. Theriogenology, 52, 1145-1152.

Lin, T. (1996), Insulin-like growth factor-I regulation of the Leydig cells. In- Payne, A. H.; Hardy, M. P. and Russell, L. D. (ed). The Leydig cell. Cache River Press, Viena, IL. pp.477- 491.

Lunstra, D. D.; Ford, J. J. and Echternkamp, S. E. (1978), Puberty in beef bulls, hormone concentrations, growth, testicular development, sperm production and sexual aggressiveness in bulls of different breeds. J. Anim. Sci., 46 : (4), 1054-1062.

MacDonald, R. D. and Deaver, D. R. (1993), Testicular development in bulls treated with recombinant bovine somatotropin. J. Anim. Sci, 71, 1540-1545.

Mathews, L. S.; Enberg, B. and Norstedt, G. (1989), Regulation of rat growth hormone gene expression. J. Biol. Chem., 264, 9905-9910.

Miller, S. A.; Dykes, D. D. and Polesky, H. F. (1988), A simple salting out procedure for extracting DNA from human nucleated cells. Nucl. Acids Res., 16, 1215.

Mitra, A.; Schlee, P.; Balakrishnan, C. R. and Pirchner, F. (1995), Polymorphisms at growth hormone and prolactin loci in Indian cattle and buffalo. J. Anim. Breed Genet., 112, 71-74.

Moody, D. E.; Pomp, D.; Newman, S. and MacNeil, M. D. (1996), Characterization of DNA polymorphisms in three populations of Hereford cattle and their association with growth and maternal EPD in line 1 Hereford. J. Anim. Sci., 74, 1784-1793.

Rocha, J. L.; Baker, J. F.; Womack, J. E.; Sanders, J. O. and Taylor, J. F. (1992), Statistical associations between restriction fragment length polymorphisms and quantitative traits in beef cattle. J. Anim. Sci., 70, 3360-3370.

Rodrigues, C. V.; Pereira, J. C. C.; Razook, A. G.; Figueiredo, L. A. and Pinheiro, L. E. L. (1998), Distribuição de variantes intragênicas do hormônio de crescimento bovino em touros Nelore. Paper presented at $35^{\text {th }}$ Reunião Anual da Sociedade Brasileira de Zootecnia, Botucatu, SP.

SAS (1996), User`s guide. Version 6.1, SAS Institute Inc., Cary, North Carolina.

Schelee, P.; Graml, R.; Rottmann, O. and Pirchner, F. (1994), Influence of growth-hormone genotypes on breeding values of Simmental bulls. J. Anim. Breed. Genet., 111, 253-256.

Stryer, L. (1988), Ação hormonal. In- Bioquímica, 3. ed. Guanabara Koogan, Rio de Janeiro. pp. 797-822.
Swanlund, D. J.; N`Diaye, M. R.; Loseth, K. J.; Pryor, J. L. and Crabo, B. G. (1995), Diverse testicular responses to exogenous growth hormone and folliclestimulating hormone in prepubertal boars. Biol. Reprod., 53, 749-757.

Theilmann, J. L.; Skow, L. C.; Baker, J. F. and Womack, J. E. (1989), Restriction fragment length polymorphisms for growth hormone, prolactin, osteonectin, $\alpha$ crystallin, $\gamma$ crystalin, fibronectin and 21-steroid hydroxylase in cattle. Anim. Genet., 20, 257-266.

Unanian, M. M.; DeNise, S. K.; Zhang, H. M. and Ax, R. L. (1994), Rapid communication, polymerase chain reaction-restriction fragment length polymorphism in the bovine growth hormone gene. J. Anim. Sci., 72, 2203.

Yao, J.; Aggrey, S. E.; Zadworny, D.; Hayes, J. F. and Kühnlein, U. (1996), Sequence variations in the bovine growth hormone gene characterized by singlestrand conformation polymorphism (SSCP) analysis and their association with milk production traits in Holsteins. Genetics, 144, 1809-1816.

Zeitler, P.; Argente, J. and Chowen-Breed, J. A. (1990), Growth hormone-releasing hormone messenger ribonucleic acid in the hypothalamus of the adult male rat is increased by testosterone. Endocrinol., 127, 1362-1368.

Zhang, H. M.; Brown, D. R.; DeNise, S. K. and Ax, R. L. (1993), Rapid communication, polymerase chain reaction-restriction fragment length polymorphism analysis of the bovine somatotropin gene. J. Anim. Sci., 71, 2276.

Received: June 05, 2000; Revised: April 23, 2001; Accepted: October 10, 2001. 